\title{
MENAKAR AKAR-AKAR MULTIKULTURALISME PENDIDIKAN DI INDONESIA
}

\author{
Oleh: Dr. Adri Lundeto, M.Pd.I. \\ (Dosen FTIK IAIN Manado) \\ adrilundeto@iain-manado.ac.id
}

\begin{abstract}
Abstrak
Multikulturalisme merupakan suatu paham atau situasi-kondisi masyarakat yang tersusun dari banyak kebudayaan. Multikulturalisme sering merupakan perasaan nyaman yang dibentuk oleh pengetahuan. Pengetahuan dibangun oleh keterampilan yang mendukung suatu proses komunikasi yang efektif dengan setiap orang dari sikap kebudayaan yang ditemui dalam setiap situasi yang melibatkan sekelompok orang yang berbeda latar belakang kebudayaannya.

Multikulturalisme pendidikan di Indonesia muncul sebagai sebuah disiplin ilmu pada dekade 1960-an dan 1970-an, pendidikan berbasis multikulturalisme atau Multicultural Based Education, selanjutnya disingkat (MBE), telah didefinisikan dalam banyak cara dan dari berbagai perspektif. Dalam terminologi ilmu-ilmu pendidikan dikenal dengan peristilahan yang hampir sama dengan MBE, yakni pendidikan multikultural (Multicultural Education) seperti yang dipakai dalam konteks kehidupan multikultural negara-negara Barat.
\end{abstract}

Kata Kunci: Multikulturalisme, pendidikan , pendidikan multikultural.

\section{A. Latar Belakang}

Pertentangan etnis yang terjadi di Indonesia beberapa tahun terakhir ini mengajarkan betapa pentingnya pendidikan multikultural bagi masyarakat. Meskipun bangsa ini secara formal mengakui keragaman, namun dalam kenyataannya tidaklah demikian. Sudah sejak lama sistem pendidikan kita terpenjara dalam pemenuhan target sebagai akibat dari kapitalisme yang telah menguasai negeri ini, sehingga memunculkan apa yang disebut dengan konsep link and match. ${ }^{1}$ Dengan demikian, pendidikan tidak lebih dari pabrik raksasa yang menghasilkan tenaga kerja terampil, namun dengan bayaran murah.

Tragedi kekerasan antar kelompok yang meledak secara sporadik diakhir tahun 1990-an sampai sekarang di berbagai kawasan di Indonesia menunjukkan betapa rentannya rasa kebersamaan yang dibangun dalam negara, betapa

${ }^{1}$ Syafiq A. Mughni, Pendidikan Berbasis Multikultural, sebuah pengantar dalam Choirul Mahfud, Pendidikan Multikultural (Cet. II; Yogyakarta: Pustaka Pelajar, 2008), h. xi. 
Jurnal Pendidikan Islam Iqra' Vol. 11 Nomor 2 Tahun 2017

Fakultas Tarbiyah dan Ilmu Keguruan [FTIK]

IAIN Manado

kentalnya prasangka antarkelompok dan betapa rendahnya nilai-nilai multikulturalisme masyarakat.

Multikulturalisme sebagai sebuah paham yang menekankan pada kesederajatan dan kesetaraan budaya-budaya lokal tanpa mengabaikan hak-hak dan eksistensi budaya yang lain, penting kita pahami bersama dalam kehidupan masyarakat yang multikultur seperti Indonesia. Jika tidak, dalam masyarakat kita kemungkinan besar akan selalu terjadi konflik akibat ketidaksaling pengertian dan pemahaman terhadap realitas multikultural tersebut.

Pada masa orde baru, pendidikan merupakan bagian dari indoktrinasi politik untuk mendukung rezim yang sedang berkuasa. Waktu itu hampir tidak ada ruang untuk mengungkapkan identitas lokal dalam sistem pendidikan. Yang ada hanyalah kebudayaan nasional. Warna-warna lokal dianggap sebagai sesuatu yang sekunder. Padahal lokalisme dalam pendidikan multikultural merupakan bagian yang paling penting. Disitulah setiap orang dapat melihat dirinya (self). Disitu pula orang bisa melihat keragaman orang lain.

Pada sentra-sentra kebudayaan, seperti kota-kota besar, dimana hidup berbagai macam etnis di dalamnya, pertemuan antarkebudayaan merupakan persoalan yang menarik. Dari hasil pertemuan ini timbul sebuah kreativitas baru yang pada akhirnya memperkaya kebudayaan. Kuncinya adalah kreativitas dan dinamika. Sistem kebudayaan yang demikian sangat diperlukan dalam menghadapi tantangan yang akan terjadi di masa depan.

\section{B. Permasalahan}

Dari uraian tersebut di atas, dapatlah ditarik permasalahan dalam tulisan ini sebagai berikut: bagaimana sesungguhnya akar pendidikan multikulturalisme itu? Untuk lebih jelasnya pembahasan makalah ini, maka penulis akan menguraikannya terlebih dahulu dengan pengertian multikulturalisme, dilanjutkan dengan akar sejarah multikulturalisme, pendidikan berbasis multikultural dan diakhiri dengan pendidikan multikultural di Indonesia.

\section{Pengertian Multikulturalisme}

Akar kata yang dapat digunakan untuk memahami multikulturalisme adalah kata 'kultur'. Kultur dalam Kamus Besar Bahasa Indonesia diartikan 
Jurnal Pendidikan Islam Iqra' Vol. 11 Nomor 2 Tahun 2017

Fakultas Tarbiyah dan Ilmu Keguruan [FTIK]

IAIN Manado

sebagai kebudayaan. ${ }^{2}$ Secara etimologis, multikulturalisme dibentuk dari kata multi (banyak), kultur (budaya) dan isme (aliran/paham). Secara hakiki, dalam kata itu terkandung pengakuan akan martabat manusia yang hidup dalam komunitasnya dengan kebudayaannya masing-masing yang unik dan beragam. ${ }^{3}$ Dengan demikian, setiap individu merasa dihargai sekaligus merasa bertanggung jawab untuk hidup bersama komunitasnya. Pengingkaran suatu masyarakat terhadap kebutuhan untuk diakui (politics of recognition) merupakan akar dari segala ketimpangan dalam berbagai bidang kehidupan.

Banyak ilmuan dunia yang memberikan defenisi kultur (budaya). Mereka antara lain: Elizabeth B. Taylor (1832-1917) dan L.H. Morgan (1818-1881) yang mengartikan kultur sebagai sebuah budaya yang universal bagi manusia dalam berbagai macam tingkatan yang dianut oleh seluruh anggota masyarakat. Emile Durkheim (1858-1917) dan Marcel Maus (1872-1950) menjelaskan bahwa kultur adalah sekelompok masyarakat yang menganut sekumpulan simbol-simbol yang mengikat di dalam sebuah masyarakat untuk diterapkan. Franz Boas (1858-1942) dan A.L. Kroeber (1876-1960) mendefinisikan bahwa kultur adalah hasil dari sebuaah sejarah-sejarah khusus umat manusia yang melewatinya secara bersamasama di dalam keolmpoknya. A.R. Radcliffe Brown (1881-1955) dan Bronislaw Malinowski (1884-1942) menggambarkan kultur sebagai sebuah praktik sosial yang memberikan support terhadap struktur sosial untuk memenuhi kebutuhankebutuhan individunya. ${ }^{4}$

Ruth Benedict (1887-1948) dan Margareth Mead (1901-1978) menjelaskan bahwa kultur adalah kepribadian yang ditulis dengan luas; bentukbentuk dan sekaligus terbentuknya kepribadian tersebut ditentukan oleh kepribadian para anggotanya. Julian Steward (1902-1972) dan Leslie White (1900-1975) menjelaskan bahwa kultur adalah sebuah cara bagi manusia untuk

${ }^{2}$ Departemen Pendidikan Nasional, Kamus Besar Bahasa Indonesia, Edisi III (Jakarta: Balai Pustaka, 2005), h. 611. Lihat juga dalam makalah Parsudi Suparlan, "Menuju Masyarakat Multikultural", dalam Simposium Internasional di Bali ke-3, Jurnal Antropologi Indonesia, Denpasar Bali, 16-21 Juli 2002.

${ }^{3}$ Choirul Mahfud, Pendidikan Multikultural, op.cit., h. 75.

4 M. Ainul Yaqin, Pendidikan Multikultural, Cross-Cultural Understanding untuk Demokrasi dan Keadilan (Yogyakarta: Pilar Media, 2005), h. 27. 
Jurnal Pendidikan Islam Iqra' Vol. 11 Nomor 2 Tahun 2017

Fakultas Tarbiyah dan Ilmu Keguruan [FTIK]

IAIN Manado

beradaptasi dengan lingkungannya dan membuat hidupnya terjamin. Morton Fried (1923-1986) dan Marvin Haris (1927) mendefinisikan kultur sebagai sebab-sebab fisik dan ekonomis yang dapat menyebabkan munculnya kultur itu sendiri dan juga sekaligus dapat menyebabkan perubahan-perubahan di dalamnya. Claude Levi-Strauss (1908) berpendapat bahwa semua kultur adalah refleksi dari struktur biologis yang universal dari pikiran manusia. Mary Douglas (1921) dan Cliffort Geertz (1926) berpendapat bahwa kultur adalah sebuah cara yang dipakai oleh semua anggota dalam sebuah kelompok masyarakat untuk memahami siapa diri mereka dan untuk memberi arti pada kehidupan mereka. ${ }^{5}$

Pengertian kultur atau kebudayaan yang telah dikemukakan di atas memang sangat beragam, namun harus dipersamakan atau setidak-tidaknya tidak dipertentangkan antara satu konsep dengan konsep lainnya. Karena multikulturalisme itu adalah sebuah ideologi dan sebuah alat atau wahana untuk meningkatkan derajat manusia dan kemanusiaannya, maka konsep kebudayaan harus dilihat dalam perspektif fungsinya bagi kehidupan manusia.

Dalam perspektif tersebut, kebudayaan adalah sebagai pedoman bagi kehidupan manusia. Yang juga harus diperhatikan bersama menyangkut kesamaan pendapat dan pemahaman adalah bagaimana kebudayaan itu bekerja melalui pranata-pranata sosial. Sebagai sebuah ide atau ideologi, multikulturalisme terserap ke dalam berbagai interaksi yang ada dalam berbagai struktur kegiatan kehidupan manusia yang tercakup dalam kehidupan sosial, kehidupan ekonomi dan bisnis, kehidupan politik dan berbagai kegiatan lainnya di dalam masyarakat yang bersangkutan. Kajian mengenai corak kegiatan interaksi sosial, yaitu hubungan antarmanusia dalam berbagai manajemen pengelolaan sumber daya, akan merupakan sumbangan yang penting dalam kehidupan bermasyarakat, berbangsa dan bernegara bagi bangsa Indonesia.

Dalam membahas tentang pengertian kultur, setidaknya ada beberapa karakter khusus yang berkaitan dengan kultur tersebut; Pertama, kultur adalah sesuatu yang general dan spesifik sekaligus. General artinya setiap manusia di dunia ini mempunyai kultur, dan spesifik berarti setiap kultur pada kelompk

\footnotetext{
${ }^{5}$ Ibid. h. 28.
} 
Jurnal Pendidikan Islam Iqra' Vol. 11 Nomor 2 Tahun 2017

Fakultas Tarbiyah dan Ilmu Keguruan [FTIK]

IAIN Manado

masyarakat bervariasi antara satu dengan lainnya. Kedua, kultur adalah sesuatu yang dipelajari. Ketiga, kultur adalah sebuah simbol. Dalam hal ini, simbol dapat berbentuk sesuatu yang verbal dan non-verbal, dapat juga berbentuk bahasa khusus yang hanya dapat diartikan secara khusus pula. Keempat, kultur dapat membentuk dan melengkapi sesuatu yang alami. Secara alamiah, manusia harus makan dan mendapatkan energi, kemudian kultur mengajarkan pada manusia untuk makan makanan jenis apa saja, kapan waktu makan dan bagaimana cara makannya. Kelima, kultur adalah sesuatu yang dilakukan secara bersama-sama yang menjadi atribut bagi individu sebagai anggota dari kelompok masyarakat. Keenam, kultur adalah sebuah model. Artinya, kultur bukan kumpulan adat istiadat dan kepercayaan yang tidak ada artinya sama sekali. Kultur adalah sesuatu yang disatukan dan sistem-sistem yang tersusun dengan jelas. Ketujuh, kultur sesuatu yang bersifat adaptif, artinya kultur merupakan sebuah proses bagi sebuah populasi untuk membangun hubungan yang baik dengan lingkungan di sekitarnya sehingga semua anggotanya melakukan usaha maksimal untuk bertahan hidup dan melanjutkan keturunan. ${ }^{6}$ Karakteristik-karakteristik biologis maupun kultural yang dipakai dalam proses bertahan hidup dan melanggengkan keturunan ini kemudian disebut sebagai sesuatu yang adaptif. Dari karakteristik ini, dapat dikembangkan pemahaman dan pemaknaan terhadap multikulturalisme, yaitu sebuah paham tentang kultur yang beragam. Dalam keragaman kultur ini meniscayakan adanya pemahaman, saling pengertian, toleransi dan sejenisnya, agar tercipta suatu kehidupan yang damai dan sejahtera serta terhindar dari konflik berkepanjangan.

Multikulturalisme merupakan suatu paham atau situasi-kondisi masyarakat yang tersusun dari banyak kebudayaan. Multikulturalisme sering merupakan perasaan nyaman yang dibentuk oleh pengetahuan. Pengetahuan dibangun oleh keterampilan yang mendukung suatu proses komunikasi yang efektif dengan setiap orang dari sikap kebudayaan yang ditemui dalam setiap situasi yang melibatkan sekelompok orang yang berbeda latar belakang kebudayaannya. Rasa

\footnotetext{
${ }^{6}$ Ibid., h. 6-9.
} 
Jurnal Pendidikan Islam Iqra' Vol. 11 Nomor 2 Tahun 2017

Fakultas Tarbiyah dan Ilmu Keguruan [FTIK]

IAIN Manado

aman adalah suasana tanpa kecemasan, tanpa mekanisme pertahanan diri dalam pengalaman dan perjumpaan antarbudaya. ${ }^{7}$

Multikulturalisme sebenarnya merupakan konsep dimana sebuah komunitas dalam konteks kebangsaan dapat mengakui keberagaman, perbedaan dan kemajemukan budaya, baik ras, suku, etnis dan agama. Sebuah konsep yang memberikan pemahaman bahwa sebuah bangsa yang plural atau majemuk adalah bangsa yang dipenuhi dengan budaya-budaya yang beragam (multikultur). Bangsa yang multikultur adalah bangsa yang kelompok-kelompok etnik atau budaya (etnic and cultural groups) yang ada dapat hidup berdampingan secara damai dalam prinsip co-existence yang ditandai oleh kesediaan untuk menghormati budaya lain. ${ }^{8}$ Pluralitas ini juga dapat ditangkap oleh agama, selanjutnya agama mengatur untuk menjaga keseimbangan masyarakat yang plural tersebut.

Pengertian multikulturalisme dan pluralisme sendiri menimbulkan beragam pandangan. Sebagian besar pendapat menyebutkan bahwa antara pluralisme dan multikulturalisme tidak terdapat perbedanan secara signifikan. Namun, ada juga yang melihat dari sisi perbedaan. Menurut Parsudi Suparlan, pada dasarnya masyarakat plural mengacu kepada suatu tatanan masyarakat yang di dalamnya terdapat berbagai unsur masyarakat yang memiliki ciri-ciri budaya yang berbeda satu sama lain. Masing-masing unsur relatif hidup dalam dunianya sendiri, bahkan kadang corak hubungan tersebut dominatif dan diskriminatif. Sedangkan mayarakat multikultural adalah suatu tatanan masyarakat yang memiliki cirri berupa interaksi yang aktif diantara unsur-unsurnya melalui proses belajar. Kedudukan dalam unsur tersebut berada dalam posisi posisi yang setara, demi terwujudnya keadilan diantara berbagai macam unsur yang salin berbeda. ${ }^{9}$

Walaupun ada yang memahami secara berbeda antara pluralisme dan multikulturalisme, tetapi perbedaannya tidaklah signifikan. Bahkan secara umum terdapat lebih banyak kesamaan diantara kedua konsep tersebut. Oleh karena itu,

\footnotetext{
h, 16 .

${ }^{7}$ Alo Liweri, Makna Budaya dalam Komunikasi Antarbudaya (Yogyakarta: LKiS, 2003),

${ }^{8}$ Nanih Mahendrawati dan Ahmad Syafei, Pengembangan Masyarakat Islam: Dari Ideologi, Strategi sampai Tradisi (Bandung: Remaja Rosdakarya, 2001), h. 34.

${ }^{9}$ Alo Liweri, loc.cit.
} 
Jurnal Pendidikan Islam Iqra' Vol. 11 Nomor 2 Tahun 2017

Fakultas Tarbiyah dan Ilmu Keguruan [FTIK]

IAIN Manado

untuk menghindari diversitas makna dan mempertegas makna antara satu dengan yang lainnya, kedua kata tersebut diintegrasikan sebagai sebuah konsep yang saling berkaitan.

\section{Akar Sejarah Multikulturalisme}

Secara historis, sejak jatuhnya Presiden Soeharto dari kekuasaannya yang kemudian diikuti dengan masa yang disebut sebagai 'era reformasi', kebudayaan Indonesia cenderung mengalami disintegrasi. Dalam pandangan Azyumardi Azra, bahwa krisis moneter, ekonomi dan politik yang bermula sejak akhir 1997, pada gilirannya juga telah mengakibatkan terjadinya krisis sosio-kultural dalam kehidupan bangsa dan negara. Jalinan tenun masyarakat (fabric of society) tercabik-cabik akibat berbagai krisis yang melanda masyarakat. ${ }^{10}$

Krisis sosial budaya yang meluas itu dapat disaksikan dalam berbagai bentuk disorientasi dan dislokasi banyak kalangan masyarakat kita, misalnya: disintegrasi sosial-politik yang bersumber dari euphoria kebebasan yang nyaris kebablasan; lenyapnya kesabaran sosial (social temper) dalam menghadapi realitas kehidupan yang semakin sulit sehingga mudah mengamuk dan melakukan berbagai tindakan kekerasan dan anarki; merosotnya penghargaan dan kepatuhan terhadap hukum, etika, moral dan kesantunan sosial; semakin meluasnya penyebaran narkotika dan penyakit-penyakit sosial lainnya; berlanjutnya konflik dan kekerasan yang besumber atau sedikitnya bernuansa politis, etnis dan agama seperti terjadi di Aceh, Kalimantan Barat dan Tengah, Maluku, Ambon, Poso dan lain-lain.

Disorientasi, dislokasi atau krisis sosial-budaya dikalangan masyarakat kita semakin merebak seiring dengan kian meningkatnya penetrasi dan ekspansi budaya Barat, khususnya Amerika sebagai akibat proses globalisasi yang terus tidak terbendung. Berbagai ekspresi sosial-budaya yang sebenarnya 'alien' (asing), yang tidak memiliki basis dan preseden kulturalnya dalam masyarakat kita sehingga memunculkan kecenderugan-kecenderungan 'gaya hidup' baru yang tidak selalu sesuai dengan dan kondusif bagi kehidupan sosial budaya masyarakat

${ }^{10}$ Azyumardi Azra, Identitas dan Krisis Budaya, Membangun Multikulturalisme Indonesia, http://kongres. Budpar.go.id/agenda/precongres/makalah/abstrak/azyumardi.htm. 
Jurnal Pendidikan Islam Iqra' Vol. 11 Nomor 2 Tahun 2017

Fakultas Tarbiyah dan Ilmu Keguruan [FTIK]

IAIN Manado

dan bangsa. Hal ini bisa dilihat misalnya dari semakin merebaknya budaya McDonald, juga makanan instan lainnya dan dengan demikian budaya serba instant; meluasnya budaya telenovela, yang menyebarkan permisivisme, kekerasan dan hedonisme; mewabahnya MTVisasi, Valentine's day dan kini juga pub night dikalangan remaja bahkan orang tua. Gejala ini tidak lain daripada 'cultural imperialisme' baru, yang menggantikan imperialisme klasik yang terkandung dalam 'orientalisme'.

Dari berbagai kecenderungan ini, orang bisa menyaksikan kemunculan kultur hybrid, budaya gado-gado tanpa identitas di Indonesia dewasa ini. Pada satu segi, kemunculan budaya hybrid tampaknya tidak terelakkan, khususnya karena proses globalissi yang semakin sulit dihindari. Tetapi pada segi yang lain, budaya hybrid apalagi yang bersumber dari dan didominasi oleh budaya luar, karena dominasi dan hegemoni politik, ekonomi dan informasi mereka dapat mengakibatkan krisis budaya nasional dan lokal lebih lanjut. Tidak hanya itu, budaya hybrid dapat mengakibatkan lenyapnya identitas kultural nasional dan lokal; padahal identitas nasional dan lokal tersebut mutlak diperlukan bagi terwujudnya integrasi sosial, kulutral dan politik masyarakat dan negara-bangsa Indonesia.

Menurut Furnivall, masyarakat plural adalah masyarakat yang terdiri dari dua atau lebih unsur-unsur atau tatanan-tatanan sosial yang hidup berdampingan, tetapi tidak bercampur dan menyatu dalam satu unit politik tunggal. ${ }^{11}$ Teori Furnivall ini banyak berkaitan dengan realitas sosial politik Eropa yang relatif 'homogen', tetapi sangat diwarnai chauvinisme etnis, rasial, agama dan gender. Berdasarkan kerangka sosial-kultural, politik dan pengalaman Eropa, Furnivall memandang masyarakat-masyarakat plural Asia Tenggara khususnya Indonesia, akan terjerumus ke dalam anarki jika gagal menemukan formula federasi pluralis yang memadai. ${ }^{12}$

Akar sejarah multikulturalisme bisa dilacak secara historis, bahwa sedikitnya selama tiga dasawarsa kebijakan yang sentralistis dan pengawalan 1944), h. 446.

${ }^{11}$ JS. Furnivall, Netherlands India: A Study of Plural Economy (New York: MacMillan, ${ }^{12}$ Ibid, h. 468. 
Jurnal Pendidikan Islam Iqra' Vol. 11 Nomor 2 Tahun 2017

Fakultas Tarbiyah dan Ilmu Keguruan [FTIK]

IAIN Manado

yang ketat terhadap isu perbedaan telah menghilangkan kemampuan masyarakat untuk memikirkan, membicarakan dan memecahkan persoalan yang muncul karena adanya perbedaan secara terbuka, rasional dan damai. ${ }^{13}$ dalam konteks global, setelah tragedi 11 September 2001 dan invasi Amerika Serikat ke Irak serta hiruk pikuk politis identitas dalam era reformasi menambah kompleksnya persoalan keragaman dan antar kelompok di Indonesia. Sejarah menunjukkan, pemaknaan secara negatif atas keragaman (pluralitas) telah melahirkan penderitaan panjang umat manusia. Pada saat ini, paling tidak telah terjadi berbagai macam pertikaian dari Barat sampai Timur, dari Utara hingga Selatan. Dunia menyaksikan darah mengalir dari Yugoslavia, Cekoslovakia, Zaire hinga Rwanda, dari bekas Uni Soviet sampai Sudan, dari Srilangkan, India hingga Indonesia. Bahkan yang sekarang sedang terjadi di Palestina, dimana ribuan rakyat tak berdosa harus dibantai demi mempertahankan identitasnya sebagai orang yang merdeka. Konflik panjang tersebut melibatkan sentimen etnis, ras, golongan dan juga agama.

Paling tidak ada tiga kelompok sudut pandang yang biasa berkembang dalam menyikapi perbedaan identitas kaitannya dengan konflik yang sering muncul. Pertama, pandangan kaum primordialis. Kelompok ini menganggap bahwa perbedaan genetika, seperti suku, ras (juga agama), merupakan sumber utama lahirnya benturan kepentingan etnis dan agama. Kedua, pandangan kaum instrumentalis. Menurut mereka, suku, agama dan identitas yang lain dianggap sebagai alat yang digunakan individu atau kelompok untuk mengejar tujuan yang lebih besar, baik dalam bentuk materiil maupun non-materiil. Konsepsi ini lebih banyak digunakan oleh politisi dan para elit untuk mendapatkan dukungan dari kelompok identitas. Ketiga, pandangan kaum konstruktivis, beranggapan bahwa identitas kelompok tidak bersifat kaku, sebagaimana yang dibayangkan kaum primordialis. Etnisitas, bagi kelompok ini dapat diolah hingga membentuk jaringan relasi pergaulan sosial. Karenanya, etnisitas merupakan sumber kekayaan hakiki yang dimiliki manusia untuk saling mengenal dan memperkaya budaya.

\footnotetext{
${ }^{13}$ Choirul Mahfud, op.cit., h. 87.
} 
Jurnal Pendidikan Islam Iqra' Vol. 11 Nomor 2 Tahun 2017

Fakultas Tarbiyah dan Ilmu Keguruan [FTIK]

IAIN Manado

Bagi mereka, persamaan adalah anugerah dan perbedaan adalah berkah. ${ }^{14}$ Dalam pandangan yang ketiga, terdapat ruang wacana tentang multikulturalisme dan pendidikan multikultural sebagai sarana membangun toleransi atas keragaman. Wacana ini mulai ramai dibicarakan dikalangan akademisi, praktisi budaya dan aktifis di awal tahun 2000-an di Indonesia.

\section{E. Pendidikan Berbasis Multikultural}

Sejak kemunculannya sebagai sebuah disiplin ilmu pada dekade 1960-an dan 1970-an, pendidikan berbasis multikulturalisme atau Multicultural Based Education, selanjutnya disingkat (MBE), telah didefinisikan dalam banyak cara dan dari berbagai perspektif. Dalam terminologi ilmu-ilmu pendidikan dikenal dengan peristilahan yang hampir sama dengan MBE, yakni pendidikan multikultural (Multicultural Education) seperti yang dipakai dalam konteks kehidupan multikultural negara-negara Barat. ${ }^{15}$ Sejumlah definisi terikat dalam disiplin ilmu tertentu, seperti pendidikan antropologi, sosiologi, psikologi dan lain sebagainya.

Ada definisi klasik untuk menekankan dimensi konseptual MBE yang penting bagi para pendidik. ${ }^{16}$ Yakni menekankan esensi MBE sebagai perspektif yang mengakui realitas politik, sosial dan ekonomi yang dialami oleh masingmasing individu dalam pertemuan manusia yang kompleks dan beragam (plural) secara kultur. Defenisi ini juga bermaksud merefleksikan pentingnya budaya, ras, gender, etnisitas, agama, status sosial, ekonomi dan pengecualian-pengecualian dalam proses pendidikan. Dalam satu dekade terakhir, Hernandez mengembangkan sebuah defenisi operasional tentang MBE. Dalam konseptualisasinya, MBE adalah sebuah kegiaan pendidikan yang bersifat empowering. Oleh karenanya, MBE menurutnya adalah sebuah visi tentang pendidikan yang selayaknya dan seharusnya bisa untuk semua peserta didik. Berkaitan dengan peserta didik, MBE menyoal tentang etnisitas, gender, kelas, bahasa, agama dan pengecualian-pengecualian yang memengaruhi, membentuk

${ }^{14}$ Ibid., h. 90.

${ }^{15}$ Hilda Hernandez, Multicultural Education: A Teacher Guide to Linking Context, Process and Content (New Jersey \& Ohio: Pentice Hall, 1989), h. 5.

${ }^{16}$ Ibid., h. 6. 
Jurnal Pendidikan Islam Iqra' Vol. 11 Nomor 2 Tahun 2017

Fakultas Tarbiyah dan Ilmu Keguruan [FTIK]

IAIN Manado

dan mempola tiap-tiap individu sebagai makhluk budaya. MBE adalah hasil perkembangan seutuhnya dari konstelasi/interaksi untik masing-masing individu yang memiliki kecerdasan, kemampuan dan bakat. MBE mempersiapkan peserta didik bagi kewarganegaraan (citizenship) dalam komunitas budaya dan bahasa yang majemuk dan saling terkait.

MBE juga berkenan dengan perubahan pendidikan yang signifikan. Ia menggambarkan realitas budaya, politik, sosial dan ekonomi yang kompleks, yang secara luas dan sistematis memengaruhi segala sesuatu yang terjadi dalam sekolah dan luar ruangan. Ia menyangkut seluruh asset pendidikan yang termanifestasikan melalui konteks, proses dan muatan (content). MBE menegaskan dan memperluas kembali praktek yang patut dicontoh dan berupaya memperbaiki berbagai kesempatan pendidikan optimal yang tertolak. Ia memperbincangkan seputar penciptaan lembaga-lembaga pendidikan yang menyediakan lingkungan pembelajaran yang dinamis, yang mencerminkan cita-cita persamaan, kesetaraan dan keunggulan.

\section{F. Pendidikan Multikultural di Indonesia}

Hingga saat ini, wacana pendidikan multikultural di Indonesia belum tuntas dikaji oleh berbagai kalangan, termasuk para pakar dan pemerhati pendidikan sekalipun. Tulisan ini dimaksudkan sebagai sumbangsih pemikiran terhadap fenomena aktual tentang wacana baru dalam dunia pendidikan di Indonesia, yakni pendidikan multikultural.

Perlu diketahui bahwa di Indonesia pendidikan multikultural relatif baru dikenal sebagai suatu pendekatan yang dianggap lebih sesuai bagi masyarakat Indonesia yang heterogen, plural. Terlebih pada masa otonomi dan desentralisasi yang baru diberlakukan sejak 1999 hingga saat ini. Pendidikan multikultural yang dikembangkan di Indonesia sejalan dengan pengembangan demokrasi yang dijalankan sebagai counter terhadap kebijakan desentralisasi dan otonomi daerah (otoda). Apabila hal itu dilaksanakan dengan tidak hati-hati, justru mungkin akan menjerumuskan kita ke dalam perpecahan nasional (disintegrasi bangsa dan separatisme). 
Jurnal Pendidikan Islam Iqra' Vol. 11 Nomor 2 Tahun 2017

Fakultas Tarbiyah dan Ilmu Keguruan [FTIK]

IAIN Manado

Menurut Azyumardi Azra, ${ }^{17}$ pada level nasional, berakhirnya sentralisme kekuasaan yang pada masa Orde Baru memaksakan 'monokulturalisme' yang nyaris seragam, memunculkan reaksi balik, yang mengandung implikasi negatif bagi rekonstruksi kebudayaan Indonesia yang multikultural. Berbarengan dengan proses otonomisasi dan sentralisasi kekuasaan pemerintahan, juga terjadi peningkatan fenomena/gejala 'provinsialisme' yang hampir tumpang tindih dengan 'etnisitas'. Kecenderungan ini, jika tidak terkendali, akan dapat menimbulkan tidak hanya disintegrasi sosial-kultural yang amat parah, bahkan juga disintegrasi politik.

Model pendidikan di Indonesia, juga di negara-negara lain, menunjukkan keragaman tujuan yang menerapkan strategi dan sarana yang dipakai untuk mencapainya. Sejumlah kritikus melihat, bahwa revisi kurikulum sekolah yang dilakukan dalam program pendidikan multikultural di Inggris dan beberapa tempat di Australia dan Kanada, terbatas pada keragaman budaya yang ada: jadi, terbatas pada dimensi kognitif saja.

Penambahan informasi tentang keragaman budaya merupakan model pendidikan multikutural yang mencakup revisi atau materi pembelajaran, termasuk revisi buku-buku teks. Terlepas dari kritik atas penerapannya di beberapa tempat, revisi pembelajaran seperti yang terjadi di Amerika Serikat merupakan strategi yang dianggap paling penting dalam reformasi pendidikan dan kurikulum. Di Jepang, aktivis kemanusiaan melakukan advokasi serius untuk merevisi buku sejarah, terutama yang menyangkut peran Jepang pada Perang Dunia II di Asia. Walaupun belum diterima, usaha ini sudah mulai membuka mata sebagian masyarakat akan pentingnya perspektif baru tentang perang, agar tragedi kemanusiaan tidak terulang kembali. Sementara di Indonesia, masih diperlukan usaha yang panjang dalam merevisi buku-buku teks agar mengakomodasi kontribusi dan partisipasi yang lebih inklusif bagi warga dari berbagai latar belakang suku, agama, budaya dan etnis. Di Indonesia juga memerlukan materi pembelajaran yang bisa mengatasi 'dendam sejarah' diberbagai wilayah.

${ }^{17}$ Lihat Azyumardi Azra dalam Majalah IKA UIN Syarif Hidayatullah, Menggagas Pendidikan Multikultural, Tsaqafah 1, 2, tahun 2003. 
Jurnal Pendidikan Islam Iqra' Vol. 11 Nomor 2 Tahun 2017

Fakultas Tarbiyah dan Ilmu Keguruan [FTIK]

IAIN Manado

Model lainnya, pendidikan multikultural tidak sekedar merevisi materi pembelajaran, tetapi juga melakukan reformasi dalam sistem pembelajaran itu sendiri. Affirmative Action dalam seleksi peserta didik sampai rekrutmen tenaga pengajar di Amerika adalah salah satu strategi untuk membuat perbaikan ketimpangan struktural terhadap kelompok minoritas. Contoh yang lain adalah model 'sekolah pembauran' Iskandar Muda di Medan yang memfasilitasi interaksi peserta didik dari berbagai latar belakang budaya dan menyusun program anak asuh lintas kelompok. Di Amerika Serikat, bersamaan dengan masuknya wacana tentang multikulturalisme, dilakukan berbagai lokakarya di sekolah-sekolah maupun di masyarakat luas untuk meningkatkan kepekaan sosial (sense of crisis), toleransi dan mengurangi prasangka antarkelompok. ${ }^{18}$

Untuk mewujudkan model-model tersebut, pendidikan multikultural di Indonesia perlu memakai kombinasi model yang ada, agar seperti yang diajukan Gorski, ${ }^{19}$ pendidikan multikultural dapat mencakup tiga jenis transformasi: 1) transformasi diri; 2) transformasi sekolah dan proses belajar mengajar, dan 3) transformasi masyarakat.

Selain itu, pendidikan multikultural dimungkinkan akan terus berkembang seperti bola salju (snow ball) yang menggelinding semakin membesar dan ramai diperbincangkan. Dan yang lebih penting dan kita harapkan adalah, wacana pendidikan multikultural akan dapat diberlakukan dalam dunia pendidikan di negeri yang multikultural ini. Apakah nantinya terwujud dalam kurikulum, materi dan metode, ataukah dalam wujud lainnya.

\section{G. Kesimpulan}

Pendidikan multikultural adalah pendidikan yang menghargai perbedaan. Pendidikan multikultural senantiasa menciptakan struktur dan proses dimana setiap kebudayaan bisa melakukan ekspresi. Ada dua hal yang mampu memberikan ruang kebebasan bagi semua kebudayaan untuk berekspresi dalam memujudkan pendidikan multikultural. Pertama, adalah dialog, dan kedua adalah toleransi.

\footnotetext{
${ }^{18}$ Choirul Mahfud, op.cit., h. 200.

19 Paul Gorski, Six Critical Paradigm Shiifd for Multicultural Education and The Question We Should Be Asking, dalam www.Exchange.org/multicultural.
} 
Jurnal Pendidikan Islam Iqra' Vol. 11 Nomor 2 Tahun 2017

Fakultas Tarbiyah dan Ilmu Keguruan [FTIK]

IAIN Manado

Pendidikan multikultural tidak mungkin berlangsung tanpa dialog. Dialog meniscayakan adanya persamaan diantara pihak-pihak yang terlibat. Begitu juga toleransi, merupakan sikap menerima bahwa orang lain berbeda dengan kita. Dialog dan toleransi merupakan satu kesatuan yang tidak dapat dipisahkan. Bila dialog itu bentuknya, maka toleransi itu adalah isinya. Toleransi diperlukan tidak hanya pada tataran konseptual, melainkan juga pada tingkat operasional. Inilah yang sejak lama hilang dalam sistem pendidikan kita.

\section{H. Saran}

Pembahasan tentang pendidikan multikultural di dunia dan lebih khusus lagi di Indonesia sampai saat ini belum menemukan konsep yang baku dan terbaik tentang bagaimana sesungguhnya pendidikan multikultural tersebut. Untuk itu pengkajian dan pembahasan tentang tema ini agar lebih intens lagi dilakukan untuk menemukan konsep yang lebih baik. 
Jurnal Pendidikan Islam Iqra' Vol. 11 Nomor 2 Tahun 2017

Fakultas Tarbiyah dan Ilmu Keguruan [FTIK]

IAIN Manado

\section{DAFTAR PUSTAKA}

Azra, Azyumardi, dalam Majalah IKA UIN Syarif Hidayatullah, Menggagas Pendidikan Multikultural, Tsaqafah 1, 2, tahun 2003.

, Identitas dan Krisis Budaya, Membangun Multikulturalisme Indonesia,http://kongres.Budpar.go.id/agenda/precongres/makalah/abstra k/azyumardi.htm.

Departemen Pendidikan Nasional, Kamus Besar Bahasa Indonesia, Edisi III, Jakarta: Balai Pustaka, 2005.

Furnivall, JS., Netherlands India: A Study of Plural Economy, New York: MacMillan, 1944.

Gorski, Paul, Six Critical Paradigm Shiifd for Multicultural Education and The Question We Should Be Asking, dalam www.Exchange.org/multicultural.

Hernandez, Hilda, Multicultural Education: A Teacher Guide to Linking Context, Process and Content, New Jersey \& Ohio: Pentice Hall, 1989.

Liweri, Alo, Makna Budaya dalam Komunikasi Antarbudaya, Yogyakarta: LKiS, 2003.

Mahendrawati, Nanih, dan Syafei, Ahmad, Pengembangan Masyarakat Islam: Dari Ideologi, Strategi sampai Tradisi, Bandung: Remaja Rosdakarya, 2001.

Mughni, Syafiq A., Pendidikan Berbasis Multikultural, sebuah pengantar dalam Choirul Mahfud, Pendidikan Multikultural, Cet. II; Yogyakarta: Pustaka Pelajar, 2008.

Suparlan, Parsudi, "Menuju Masyarakat Multikultural", dalam Simposium Internasional di Bali ke-3, Jurnal Antropologi Indonesia, Denpasar Bali, 16-21 Juli 2002.

Yaqin, M. Ainul, Pendidikan Multikultural, Cross-Cultural Understanding untuk Demokrasi dan Keadilan, Yogyakarta: Pilar Media, 2005. 